\title{
Upaya Meningkatkan Kemampuan Guru Matematika Kota Surakarta dalam Menyusun Soal PISA-like
}

\author{
Imam Sujadi $^{1}$, Budiyono ${ }^{2}$, Ira Kurniawati ${ }^{3}$, Arum Nur Wulandari ${ }^{4}$, Riki Andriatna ${ }^{5}$ \\ Prodi Pendidikan Matematika, FKIP, Universitas Sebelas Maret Surakarta \\ arumnurwulandari@gmail.com
}

\begin{abstract}
ABSTRAK
Mitra kegiatan pengabdian kepada masyarakat ini adalah MGMP Matematika SMP Kota Surakarta. Berdasarkan hasil evaluasi pengabdian tahun 2018 didapatkan guru masih kesulitan untuk melatih siswa dalam menyelesaikan soal HOTS, termasuk didalamnya soal pemecahan masalah dan soal penalaran sebagaimana soal PISA serta mengintegrasikan dalam pembelajaran. Siswa dapat memecahkan soal hanya jika guru menjelaskan secara runtut dan sistematis prosedur pemecahannya. Masalah lain yang dihadapi adalah kurang tersedianya soal PISA-like yang didesain khusus untuk mengembangkan penalaran siswa. Tim Pengabdian bekerjasama dengan mitra menyelenggarakan kegiatan pendampingan guru dalam menyusun sendiri soal matematika PISA-like. Kegiatan ini melibatkan 34 guru dan dilaksanakan secara daring dalam 4 tahap, meliputi: (1) pembekalan materi mengenai PISA serta penilaian dan pembelajaran di masa pandemi, (2) inspirasi penyusunan soal PISAlike dan praktik penyusunan soal, (3) diskusi hasil penyusunan soal (4) implementasi. Hasil kegiatan ini menunjukkan bahwa: (1) 97\% peserta menyatakan dengan kegiatan pendampingan wawasan mengenai karakteristik soal PISA dalam berbagai konteks (Personal, Societal, Occupational, Scientific) dan konten (Shape and Space, Change and Relationship, Quantity, dan Uncertainty) meningkat, (2) setelah mengikuti kegiatan pendampingan, peserta mampu menyusun soal sejenis PISA, (3) tindak lanjut kegiatan ini peserta dapat mengimplementasikan soal untuk kemudian menganalisis kesulitan siswa, serta mencari alternatif pembelajaran yang mampu mengatasi kesulitan tersebut.
\end{abstract}

Kata kunci: kemampuan guru, matematika, menyusun soal, PISA-like

\section{ABSTRACT}

The partner of this community service activity is the Mathematics MGMP of the Surakarta City Junior High School. Based on the results of the 2018 service evaluation, it was found that teachers still had difficulty in training students in solving HOTS questions, including problem solving and reasoning questions as well as PISA questions and integrating them into learning. Students can solve problems only if the teacher explains in a coherent and systematic way the solving procedures. Another problem faced is the lack of availability of PISA-like questions that are specifically designed to develop students' reasoning. The Service Team in collaboration with partners organizes teacher assistance activities in compiling their own PISA-like math problems. This activity involves 34 teachers and is carried out online in 4 stages, including: (1) debriefing material on PISA as well as assessment and learning during the pandemic, (2) inspiration for the preparation of PISA-like questions and practice of preparing questions, (3) discussion of the results of the preparation question (4) implementation. The results of this activity indicate that: (1) 97\% of the participants stated that with the mentoring activity, insight about the characteristics of PISA questions in various contexts (Personal, Societal, Occupational, Scientific) and content (Shape and Space, Change and Relationship, Quantity, and Uncertainty) increased, (2) after participating in mentoring activities, participants are able to prepare questions similar to PISA, (3) follow-up to this activity participants can implement questions to then analyze student difficulties, and look for learning alternatives that are able to overcome these difficulties.

Keywords: teacher's ability, mathematics, compiling questions, PISA-like

\section{PENDAHULUAN}

Sejalan dengan dicanangkanya

kebijakan "Merdeka Belajar" oleh pemerintah, yang berkonotasi pada "Kemerdekaan Berfikir", makin memberi peluang yang seluasluasnya bagi guru dan sekolah untuk mengembangkan kreativitas dan inovasi dalam mendesain sebuah rencana pelaksanaan serta melaksanakan proses pembelajaran. Keseluruhan proses tentunya bermuara pada pencapaian kompetensi siswa secara komprehensif, baik pada ranah pengetahuan, 
keterampilan, dan sikap siswa, sebagaimana tertuang dalam Standar Kompetensi Lulusan (SKL) yang diharapkan. Pelaksanaan UN akan diubah menjadi Asesmen Kompetensi Minimum dan Survei Karakter, yang terdiri dari kemampuan bernalar menggunakan bahasa (literasi), kemampuan bernalar menggunakan matematika (numerasi), dan penguatan pendidikan karakter. Arah kebijakan ini juga mengacu pada praktik baik pada level internasional seperti PISA dan TIMSS (Hendri, 2020).

Bersamaan dengan itu, kebijakan Kementerian Pendidikan dan Kebudayaan (Kemendikbud) saat ini, lebih diarahkan pada penyederhanaan/penyesuaian Kompetensi Dasar (KD), penyederhanaan RPP, pelaksanaan pembelajaran secara kontekstual, dan mengutamakan penilaian formatif selama proses pembelajaran, dengan tetap berfokus pada kecakapan global, yaitu literasi, penguatan karakter, dan kecakapan abad 21 (Critical Thinking, Creativity, Communication, dan Collaboration/ 4C). Salah satu ketrampilan yang perlu dikembangkan yaitu kemampuan penalaran (reasoning) merupakan salah satu komponen proses standar selain kemampuan pemecahan masalah, representasi, komunikasi dan koneksi. Penalaran matematis siswa sangat penting untuk mengetahui dan mengerjakan matematika. Adapun aktivitas yang tercakup di dalam kegiatan penalaran matematis meliputi: menarik kesimpulan logis; menggunakan penjelasan dengan menggunakan model, fakta, sifat-sifat, dan hubungan; memperkirakan jawaban dan proses solusi; menggunakan pola dan hubungan; untuk menganalisis situasi matematik, menarik analogi dan generalisasi; menyusun dan menguji konjektur; memberikan contoh penyangkal (counter example); mengikuti aturan inferensi; memeriksa validitas argumen; menyusun argumen yang valid; menyusun pembuktian langsung, tak langsung dan menggunakan induksi matematik (Sukirwan, Dahrim, \& Herman, 2018).

$$
\text { Dalam rangka benchmarking }
$$

pencapaian program pendidikan nasional yang salah satunya adalah kemampuan bernalar, Indonesia berpartisipasi dalam berbagai studi internasional seperti PISA (Program for International Student Assessment). PISA merupakan studi yang dikembangkan oleh negara-negara maju di dunia yang tergabung dalam OECD (Organisation for Economic Cooperation and Development). Indonesia mengikuti PISA mulai tahun 2000 hingga terakhir pada tahun 2018 Indonesia berada pada poisisi 74 dari 79 negara peserta. Laporan internasional di enam periode tersebut menunjukkan bahwa hasil tes siswa Indonesia masih di bawah nilai rata-rata internasional (Hewi \& Shaleh, 2020). Setelah dilakukan beberapa analisis oleh para peneliti pendidikan yang dikoordinir oleh Kementerian Pendidikan dan Kebudayaan ditemukan beberapa faktor penyebab yang diantaranya adalah kurangnya sosialisasi mengenai studi PISA dan tentang tipe tes PISA yang untuk pada siklus ini telah beralih ke sistem tes berbasis computer. Faktor penyebab ini dilatarbelakangi dengan permasalahan ketidakbiasaan siswa di kelas mendapat soal-soal PISA-like.

Masalah yang dihadapi oleh guru adalah kurang tersedianya soal-soal yang didesain khusus yang sesuai dengan potensi siswa dan karakter siswa sehingga diasumsikan bahwa soal tersebut akan membantu mengembangkan potensi siswa menggunakan penalaran (reasoning). Agar siswa terbiasa dengan soal tersebut maka guru perlu diberikan sosialisasi tentang apa dan bagaimana karakteristik dan framework tentang soal-soal PISA dengan cara mengembangkan dan mengadaptasikan soal-soal model PISA untuk diimplementasikan dalam proses pembelajaran di kelas. Apabila hal ini bisa diantisipasi dengan baik, kemudian guru mau mengupayakan perbaikan sistem pembelajaran yang saat ini ada, dengan mengenalkan soal PISA-like dalam formatif tes yang dilakukan dalam pembelajaran, maka pada tahun 2022 capaian PISA di Indonesia berpeluang akan mendekati capaian rerata negara-negara OECD.

Meskipun demikian tidak mudah bagi sekolah untuk mewujudkannya dengan baik dan tepat, apalagi situasi pandemi covid-19 saat ini yang menyebabkan sekolah melakukan PJJ. Kebijakan ini menjadi masalah terutama bagi sekolah dengan fasilitas yang sederhana dan sumber daya pengajar yang memiliki kemampuan teknologi sederhana (Yusron, Wijayanti, \& Novitasari, 2020). Hal ini membutuhkan penguatan dan pendampingan, agar para guru mampu memenuhi harapan masyarakat, yaitu PJJ yang berkualitas dan sesuai dengan situasi serta kondisi daerah masing-masing dengan kualitas hasil belajar yang baik, sehingga perlu pengenalan lebih pada tipe tes PISA dan bagaimana rencana dan strategi pembelajaran di kelas untuk dapat menuju kepada hasil yang diharapkan oleh studi PISA.

Mengacu kepada profil mitra yaitu MGMP matematika SMP Kota Surakarta, 
permasalahan yang terjadi dalam pembelajaran matematika SMP Kota Surakarta antara lain sebagai berikut: (1) rendahnya hasil uji coba AKSI for School untuk tingkat SMP, khususnya pada literasi matematika, dengan hasil analisis menunjukkan bahwa siswa SMP menganggap soal yang PISA-like termasuk soal kategori sulit karena tidak memuat petunjuk dan informasi yang jelas, (2) keterbatasan dalam sosialisasi dan pemanfaatan program AKSI for School oleh Puspendik, baru satu guru yang ikut pelatihan yang dilakukan oleh Puspendik (2018), maka kegiatan desiminasi ke anggota MGMP yang harus dilakukan oleh satu orang Guru cukup berat, (3) pada tahun 2019 Surakarta tidak mendapat undangan dalam pelatihan penyusunan soal yang PISA-like, sehingga guru matematika SMP di Kota Surakarta belum mendapat pelatihan sebagaimana guru guru di Kab/Kota yang lain, (4) guru matematika masih banyak yang kesulitan dalam membelajarkan matematika dengan menyediakan soal-soal PISA-like dan juga masih kesulitan dalam mengintegrasikan pembelajaran berorientasi HOTS (Sujadi, Kurniawati, \& Wulandari, 2020) .

Dalam rangka mendorong mitra untuk dapat mengatasi permasalahan yaitu masih rendahnya kemampuan siswa dalam memecahkan soal matematika berbasis konteks PISA dan guru merasa kesulitan untuk menyusun sendiri soal PISA-like, maka pengabdian ini mengambil langkah untuk mendampingi guru dalam menyusun sendiri soal matematika PISA-like. Apabila guru mampu membuat sendiri soal yang terkait suatu konten dengan memilih konteks yang sesuai sehingga guru bisa menyiapkan soal untuk formatif tes dengan soal-soal PISA-like. Dengan kegiatan ini diharapkan terjadi peningkatan kemampuan berpikir kritis, kemampuan penalaran dan kemampuan pemecahan masalah siswa dalam menyelesaikan soal PISA-like, baik berupa soal penalaran, pemecahan masalah maupun literasi matematika. Menindaklanjuti hal tersebut, RG Dikdasmen FKIP UNS, menyusun sejumlah materi terkait, untuk disampaikan kepada guru guru matematika SMP anggota MGMP matematika di Kota Surakarta dengan tujuan RG Dikdasmen Prodi Pendidikan Matematika FKIP bisa ikut serta berkontribusi dalam upaya meningkatkan mutu pendidikan di Indonesia melalui kegiatan Pengabdian Kepada Masyarakat.

\section{METODE KEGIATAN}

Kegiatan pengabdian kepada masyarakat dengan dilakukan secara daring dengan peserta sebanyak 34 Guru Matematika SMP Kota Surakarta. Pendampingan dilaksanakan menggunakan media zoom-meetings untuk memfasilitasi pemaparan materi dan diskusi. Pengabdian ini mengambil data kemampuan guru-guru matematika SMP di Kota Surakarta dalam menyusun sendiri soal sejenis PISA, yaitu soal yang berbasis pada konteks dengan tingkat soal terdiri dari soal ingatan dan pemahaman, soal penerapan dan soal penalaran. Sumber data adalah guru, siswa, dan kejadian yang terjadi pada proses pendampingan penyusunan soal sejenis PISA dan hasil implementasi di kelas.

Pengumpulan data dilakukan melalui metode angket dan observasi saat pelatihan dan mengimplementasikan di kelas. Instrumen yang dibutuhkan adalah lembar kerja, angket dan lembar observasi. Validasi data dilakukan melalui teknik triangulasi metode. Pendampinan dibagi menjadi 4 tahap, yaitu sebagai berikut: (1) penyampaian materi pengantar PISA dan Mengembangkan Aktifitas Pembelajaran dan Penilaian di masa Pandemi Covid 19, (2) meliputi Penyusunan soal matematika sejenis PISA, (3) diskusi soal matematika sejenis PISA untuk konten Bilangan, Aljabar, Geometri, Statistika dan Peluang, (4) implementasi dengan memberikan soal matematika sejenis PISA kepada siswa di masing-masing sekolah.

\section{HASIL \& PEMBAHASAN}

Pengabdian dilaksakan secara daring dikarenakan adanya pandemic covid-19 yang menyebabkan diberlakukannya pembatasan kegiatan yang melibatkan banyak peserta. Walaupun demikian antusias peserta pendampingan sangat tinggi, ini ditunjukkan dari keingitahuan yang besar serta keaktifan peserta dalam mengikuti serangkaian kegiatan pendampingan ini. Kegiatan diawali dengan pemaparan materi mengenai Pengantar PISA. Materi ini berisikan penjelasan mengenai apa itu PISA, manfaat PISA, mengapa Indonesia mengikuti PISA dan apa yang diukur dalam PISA. Sebagian besar guru mengetahui bahwa pencapaian Indonesia khususnya pada literasi matematika tidak terlalu menggembirakan. Namun pada PISA 2018 dilakukan oversample provinsi DKI dan DIY menunjukkan bahwa rerata skor kedua provinsi tersebut untuk matematika khususnya lebih tinggi 
dibandingkan hasil nasional serta sejajar dengan Negara ASEAN lainya. Hal ini mengindikasikan terjadi kesenjangan mutu pendidikan. Dari sini peserta pelatihan mengetahui bahwa dengan usaha perbaikan mutu Indonesia harusnya bisa mengejar ketertinggalan dalam hal pencapaian hasil PISA. Salah satunya dengan membiasakan siswa untuk memecahkan soal-soal PISA-like.

Materi inti yang kedua yaitu mengenai Framework PISA. Dari tanya jawab dengan guru peserta pelatihan, sebagian besar memiliki anggapan bahwa Tes PISA memuat soal-soal yang memiliki tingkat kesulitan yang tinggi atau yang lebih sering dikenal dengan HOTS. Hal ini tidak salah karena memang sebagian besar soal PISA merupakan soal HOTS. Akan tetapi guru juga perlu mengetahui bahwa soal PISA merupakan soal-soal yang mengukur kemampuan siswa menggunakan konten matematika (Bilangan, Aljabar, Geometri, Peluang dan Statistika) dalam konteks kehidupan sehari-hari (personal, karier, sosial, dan ilmiah) yang meliputi proses berpikir level 1 (pemahaman), level 2 (penerapan), dan level 3 (penalaran). Pada soal PISA untuk suatu konteks dapat memuat lebih dari satu soal dengan bentuk soal yang berbeda dengan proses berpikir yang juga berbeda levelnya. Soal dalam format UN/USBN selama ini merupakan soal-soal yang mengukur kemampuan siswa terkait konten matematika (Bilangan, Aljabar, Geometri, Peluang dan Statistika) dan biasanya kalau menggunakan suatu konteks/stimulus, maka setiap satu konteks hanya memuat satu soal meliputi proses berpikir level 1 (pemahaman), level 2 (penerapan), atau level 3 (penalaran). Tes PISA akan menilai bagaimana siswa menggunakan pengetahuan dan kemampuan berpikir kritis mereka untuk memahami isu-isu yang sangat penting bagi dunia (misalnya, perubahan iklim, kemiskinan) dan isu-isu yang mempengaruhi interaksi terbuka dan saling hormat antar budaya (misalnya stereotip budaya) (Dewantara, 2018). Setelah diberikan pemahaman mengenai karakteristik soal PISA, peserta pelatihan diminta untuk mencermati inspirasi soal sejenis PISA Matematika.

Setelah mendapatkan materi mengenai framework PISA dan inspirasi soal PISA diberikan pula materi tambahan mengenai inspirasi pembelajaran dan penilaian di masa pandemic. Hal ini penting dikarenakan guru masih beradaptasi dengan kondisi pembelajaran di masa pandemi ini untuk dapat merancang dan mengimplementasikan pembelajaran matematika yang efektif ditengah keterbatasan yang ada.

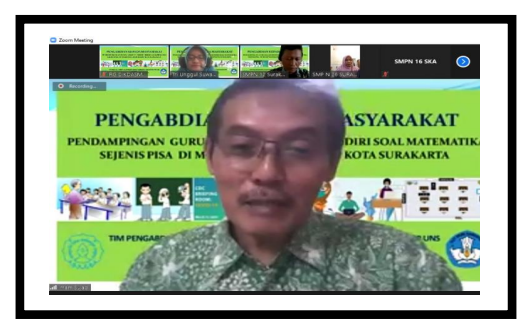

Setelah mengikuti serangkaian pemaparan materi dan tanya jawab, guru diberikan LK untuk melaksanakan praktek penyusunan soal sejenis PISA serta LK mengenai kesulitan guru dalam menyusun soal. Guru dibagi dalam beberapa kelompok untuk menyusun soal dalam berbagai konten dan konteks. Diambil sampel soal untuk didiskusikan dalam kegiatan sebagai berikut: "Dalam situasi wabah virus korona di bulan Maret 2020 ini, setiap orang diminta mematahui himbauan dari pemerintah, yaitu tetap di rumah dengan bekerja dari rumah, belajar dari rumah. Selain itu, setiap orang diminta untuk tetap menjaga kesehatan dengan makan makanan bergizi dan olahraga. Adi adalah salah satu siswa SMP Pangudi Luhur

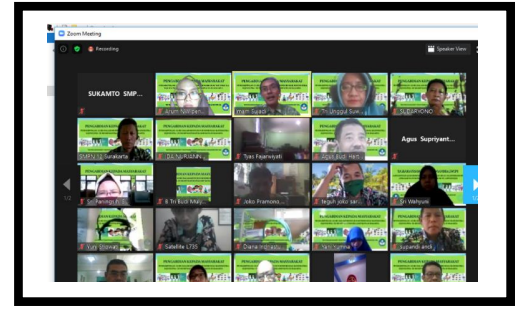

ratan

yang menaati himbauan pemerintah. Untuk menjaga kesehatan Adi setiap pagi jogging dengan rute jalan di komplek perumahannya. Dalam komplek perumahan tempat tinggal Adi , terdapat 6 rumah yang dihubungkan dengan jalan sesuai dengan sketsa gambar di bawah ini. Jarak rumah Adi ke rumah Budi sama dengan jarak rumah Doni ke rumah Candra yaitu $80 \mathrm{~m}$ dan jarak rumah Adi ke rumah Doni sama dengan jarak rumah Budi ke rumah Candra yaitu $60 \mathrm{~m}$. Pagi ini Adi menghendaki jogging dari rumahnya ke rumah Candra, dengan melalui rute terdekat. Bantulah Adi memilih rute yang paling dekat dan hitung jarak yang ditempuh Adi sesuai rute saranmu!" 


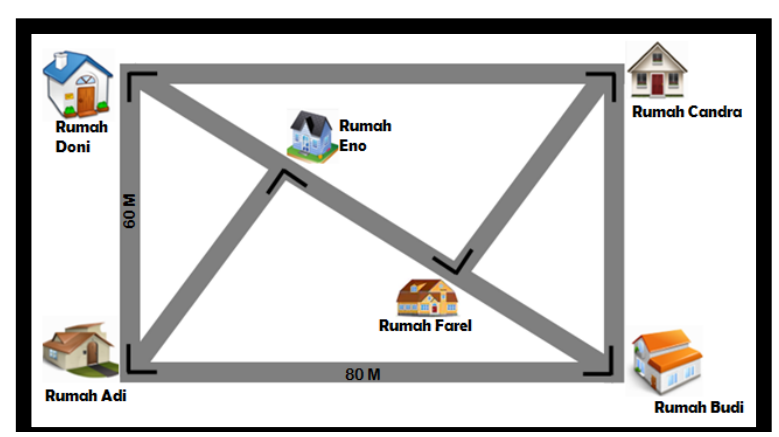

Gambar 2. Sketsa Kompleks Perumahan

Soal yang disusun sudah menunjukkan bahwa peserta memahami dengan jelas karakteristik soal sejenis PISA, peserta mengaitkan soal pada konteks personal, diberikan stimulus, gambar juga disajikan untuk menarik keingintahuan siswa. Yang lebih menarik lagi peserta dapat mengaitkan soal dengan kondisi/ konteks saat ini yaitu terjadinya wabah corona.

Selain diminta mengembangkan soal, peserta pendamping juga diminta untuk mengimplementasikan soal-soal sejenis PISA kepada siswa dalam pembelajaran daring. Soal terdiri dari empat konten, yang meliputi Konten Bilangan (Kuantitas), Konten Aljabar (Perubahan dan Hubungan), Konten Peluang dan Statistika (Ketidakpastian dan Data), dan Konten Geometri (Bentuk dan Ruang). Hasil implementasi menunjukkan jumlah skor benar terendah yang diperoleh siswa adalah untuk konten soal Aljabar yaitu sebesar 33,33\% diikuti untuk konten soal Bilangan sebesar 48,96\%. Hasil tersebut menunjukkan bahwa pada kedua konten tersebut, diduga bahwa kemampuan siswa masih rendah. Diharapkan kedepannya guru dapat rutin memberikan dan membelajarka soal-soal sejenis PISA dengan tujuan untuk membiasakan dan meningkatkan penalaran siswa. Soal PISA sangat sesuai untuk digunakan untuk melatih dan meningkatkan kemampuan penalaran matematis siswa (Azizah, Sudarni, \& Kurniati, 2017).

Peserta pendampingan juga diberikan angket untuk mengetahui respon peserta terhadap kegiatan pendampingan ini. Dari hasil angket diketahui bahwa $100 \%$ peserta menyatakan bahwa peserta menganggap pendampingan ini sangat bermanfaat. Dengan mengikuti kegiatan pendampingan ini, peserta lebih memahami tentang PISA. Lebih bersemangat untuk membuat soal sejenis PISA dan mengaplikasikan kepada peserta didik. Selain itu, $97 \%$ peserta menyatakan bahwa peserta mendapatkan ilmu baru dari kegiatan pendampingan, yaitu mengenai soal PISA dengan menggunakan konten: Bilangan, Aljabar,Geometri, Peluang, dan Statistik), dalam kontek kehidupan sehari-hari (personal, karier,sosial dan ilmiah).

Walaupun demikian tenyata beberapa peserta menyatakan masih menemui kendala dalam menyusun soal sejenis PISA. Kesulitan itu diantaranya masih terbatasnya ide untuk mengaitkan soal dengan konteks, kesulitan dalam membuat stimulus, serta harus mengkaitkan bentuk abstrak matematika ke dalam sebuah permasalahan yang dapat dipahami dan diselesaikan oleh peserta didik. Hasil lainnya menunjukkan $97 \%$ peserta menyatakan walaupun sulit kemampuan untuk dapat mengembangkan soal sejenis PISA sangat dibutuhkan karena soal-soal demikan dibutuhkan untuk melatih kemampuan bernalar dan berpikir kritis siswa. Kemampuan berpikir tingkat tinggi tersebut dibutuhkan siswa tidak hanya untuk menerapkan apa yang telah mereka pelajari, tetapi juga menganalisis, mengevaluasi, dan mensintesis pengetahuan yang mereka miliki diperoleh untuk memecahkan masalah dalam kehidupan seharihari (Pratama \& Retnawati 2018).

Peserta juga menyatakan bahwa dalam penerapan soal-soal PISA, siswa menghadapi kesulitan dalam menyelesaikannya dikarenakan siswa yang terbiasa berpikir secara linier. Jika ada soal matematika, maka akan langsung mencoba mengerjakan dengan rumus yang diberikan, padahal soal PISA bukan soal rutin yang dapat langsung dikerjakan dengan menggunakan rumus yang diberikan. Secara umum kelemahan siswa kita yaitu belum mampu memahami informasi esensial dan strategis dalam menyelesaikan soal, dan masih cenderung "menerima" informasi kemudian melupakannya, sehingga mata pelajaran matematika belum mampu menjadi "sekolah berpikir" bagi siswa (Wardhani \& Rumiati, 2011). Seluruh peserta pendampingan setuju bahwa akan ada dampak penggunaan soal sejenis PISA dalam pembelajaran terkait dengan peningkatan penalaran siswa.

\section{KESIMPULAN \& SARAN}

Dari kegiatan pendampingan yang telah dilaksanakan serta dari hasil dan pembahasan dapat diambil kesimpulan sebagai berikut: (1) kegiatan pendampingan ini dapat meningkatkan wawasan guru mengenai karakteristik soal PISA dalam berbagai konteks (Personal, Societal, Occupational, Scientific) dan konten (Shape and Space, Change and Relationship, 
Quantity, dan Uncertaintly), (2) setelah mengikuti kegiatan pendampingan, guru mampu menyusun soal sejenis PISA dengan baik pada berbagai konten dan konteks, (3) tindak lanjut dari kegiatan ini guru dapat mengimplementasikan soal di pembelajaran matematika untuk kemudian menganalisis kesulitan siswa, serta mencari alternatif pembelajaran yang mampu mengatasi kesulitan tersebut.

Kegiatan pendampingan ini dilaksanakan dalam masa pandemi Covid-19 sehingga terdapat keterbatasan dalam pelaksanaannya. Saran untuk menindaklanjuti kegiatan pengabdian ini adalah dilakukan pelatihan bagi guru-guru untuk mengembangkan pembelajaran dan media pembelajaran matematika yang efektif untuk meningkatkan kemampuan berpikir tingkat tinggi siswa. Saran dari peserta kepada Tim Pengabdi yaitu selain pendampingan dalam pembuatan soal-soal PISA, dapat dibuat pendampingan bagaimana pembelajaran yang sesuai dengan standar internasional serta bagaimana pendidikan matematika di luar negeri dilaksanakan sehingga menghasilkan siswa-siswa yang dapat mencapai nilai tinggi dalam penilaian PISA.

\section{DAFTAR PUSTAKA}

Azizah, R.F, Sunardi, \& Kurniati, D. (2017). Penalaran Matematis dalam Menyelesaikan Soal Pisa pada Siswa Usia 15 Tahun Di Sma Negeri 1 Jember. Kadikma 8(1), 97-104.

Dewantara, A.H. (2018). Soal Matematika Model Pisa: Alternatif Materi Program Pengayaan, Jurnal Dikdaktika (12)2.197213.

DOI : $10.30863 /$ didaktika.v12i2.186

Hendri, N. (2020). Merdeka Belajar, antara Retorika dan Aplikasi. Jurnal E-TECH, 8(1), 1-29. https://doi.org/10.24036/et.v8i1.107288

Hewi, L.\& Shaleh.M. (2020). Refleksi Hasil PISA (The Programme For International Student Assesment): Upaya Perbaikan Bertumpu Pada Pendidikan Anak Usia Dini). Jurnal Golden Age, Universitas Hamzanwadi (4) 1, 30-41.

Pratama G. S. \& Retnawati H. (2018). Urgency of Higher Order Thinking Skills (HOTS) content analysis in mathematics textbook J. Phys.: Conf. Ser. 1097012147 doi :10.1088/1742-6596/1097/1/012147
Puspendik. 2017. Assessmen Kompetensi Siswa Indonesia (AKSI) di Jenjang SMP Tahun 2017. Tersedia di https://puspendik.kemdikbud.go.id/semina r/upload/Seminar\%20Puspendik\%202017 /Asesmen\%20Kompetensi\%20Siswa\%20I ndonesia $\% 20($ AKSI $) \% 20$ \%20Rahmah.pdf.

Sukirwan, Dahrim, T. Herman. (2018). Analysis of students' mathematical reasoning. J. Phys.: Conf. Ser. 948012036. doi :10.1088/1742-6596/948/1/012036

Sujadi, I., Kurniawati,I. , Wulandari, A.N. (2020). Upaya Meningkatkan Pembelajaran Berorientasi HOTS Bagi Guru Matematika SMP Kota Surakarta dengan Pemanfaatan Hasil Program AKSI for School. Jurnal DEDIKASI, Comunnity Service Report 2(1), 52-57.

Wardhani, S. \& Rumiati. 2011. Instrumen Penilaian Hasil Belajar Matematika SMP: Belajar dari PISA dan TIMSS. Yogyakarta: PPPPTK.

Yusron, R.M., Wijayanti, R., \& Novitasari, A.T. (2020). Pelatihan Pembuatan Google Formbagi Guru SD Sebagai Media Evaluasi Pembelajaran Jarak Jauh (PJJ) Masa Pandemi. Jurnal Publikasi Pendidikan 10(3), 182-188. https://doi.org/10.26858/publikan.v10i3.1 $\underline{5055}$ 